\title{
Clinical cholera surveillance sensitivity in Bangladesh and implications for large-scale disease control
}

Sonia T. Hegde ${ }^{a \star}$, Elizabeth C. Lee ${ }^{a \star}$, Ashraful Islam Khan ${ }^{b}$, Stephen A. Lauer ${ }^{a}$, Md. Taufiqul Islam ${ }^{\mathrm{b}}$, Taufiqur Rahman Bhuiyan ${ }^{\mathrm{b}}$, Justin Lessler ${ }^{\mathrm{a}}$, Andrew S. Azman ${ }^{\mathrm{a}}$, Firdausi Qadrib , Emily S. Gurley ${ }^{a}$

${ }^{a}$ Department of Epidemiology, Johns Hopkins Bloomberg School of Public Health, Baltimore, MD, USA

${ }^{\mathrm{b}}$ Infectious Disease Division, icddr,b, Dhaka, Bangladesh

* denotes equal contribution

\section{Running title}

Clinical cholera surveillance in Bangladesh

\section{Abstract word count}

195 words

\section{Text word count}

2,862 words 


\section{Conflict of interest statement}

We declare no conflicts of interest.

\section{Funding}

This work was supported by the Bill \& Melinda Gates Foundation (OPP1191944 to ASA; and OPP1171700 to ASA and JL). The serological fieldwork used in this study was funded by the US Centers for Disease Control and Prevention (CDC) under a cooperative grant to icddr,b (no 5U01GH001207-02). The serological analysis was funded by the US National Institutes for Health (NIH; R01 Al135115 to ASA).

\section{Meetings where information has previously been presented}

Asian Conference on Diarrhoeal Disease and Nutrition (ASCODD), January 2020, Dhaka, Bangladesh

\section{Corresponding author}

Dr. Sonia Hegde

shegde@jhu.edu

Department of Epidemiology

Johns Hopkins Bloomberg School of Public Health

615 North Wolfe Street Rm E6038

Baltimore, MD 21205 
medRxiv preprint doi: https://doi.org/10.1101/2021.06.02.21258249; this version posted June 5, 2021. The copyright holder for this preprint (which was not certified by peer review) is the author/funder, who has granted medRxiv a license to display the preprint in perpetuity.

It is made available under a CC-BY 4.0 International license .

\section{Abstract}

2 Introduction

3 A surveillance system that is sensitive to detecting high burden areas is critical for achieving

4 widespread disease control. In 2014, Bangladesh established a nationwide, facility-based

5 cholera surveillance system for Vibrio cholerae infection. We sought to measure the sensitivity

6 of this surveillance system to detect cases to assess whether cholera elimination targets

7 outlined by the Bangladesh national control plan can be adequately measured.

8 Methods

9 We overlaid maps of nationally-representative annual $V$. cholerae seroincidence onto maps of

10 the catchment areas of facilities where confirmatory laboratory testing for cholera was

11 conducted, and identified its spatial complement as surveillance greyspots, areas where cases

12 likely occur but go undetected. We assessed surveillance system sensitivity and changes to

13 sensitivity given alternate surveillance site selection strategies.

\section{Results}

15 We estimated that $69 \%$ of Bangladeshis (111.7 million individuals) live in surveillance greyspots,

16 and that $23 \%$ (25.5 million) of these individuals live in areas with the highest $V$. cholerae

17 infection rates.

18 Conclusions

19 The cholera surveillance system in Bangladesh has the ability to monitor progress towards

20 cholera elimination goals among $31 \%$ of the country's population, which may be insufficient for

21 accurately measuring progress. Increasing surveillance coverage, particularly in the highest risk

22 areas, should be considered.

\section{Keywords}

24 Surveillance, Bangladesh, Cholera, Disease control, Elimination 
medRxiv preprint doi: https://doi.org/10.1101/2021.06.02.21258249; this version posted June 5, 2021. The copyright holder for this preprint (which was not certified by peer review) is the author/funder, who has granted medRxiv a license to display the preprint in perpetuity.

It is made available under a CC-BY 4.0 International license .

\section{Introduction}

Bangladesh has among the highest national rates of Vibrio cholerae infection in the world [1]; a nationally-representative serosurvey estimated that roughly $17 \%$ (95\% Cl: 11-24\%)

of the 165 million people living in Bangladesh experienced infection in 2015 [2]. In 2014, the

International Centre for Diarrhoeal Disease Research, Bangladesh (icddr,b) and the Institute of

31 Epidemiology Disease Control And Research (IEDCR) established a nationwide sentinel

surveillance system with the goal of monitoring the seasonality and geographic trends in acute

cases and identifying geographic areas with a high burden of laboratory-confirmed clinical cholera [3]. The participating 22 sentinel hospital sites and the icddr,b Dhaka hospital are the only healthcare facilities that regularly perform laboratory confirmation of $V$. cholerae in the country [3].

The government of Bangladesh proposed their first national cholera control plan in 2019, with the ambitious goals of reducing morbidity and mortality by $50 \%$ by 2025 and $90 \%$ by 2030 and achieving cholera elimination [4]. Few comparative, nationally representative data exist in Bangladesh, however, with which to compare and measure the reduction in morbidity and mortality. While vaccination campaigns, water, sanitation, and hygiene interventions, and

42 improved case management are the primary tools to achieve these elimination targets, a

43 cholera surveillance system with widespread geographical coverage is necessary to target

44 interventions to the highest burden areas and monitor progress from endemic transmission to 45 elimination.

47 framework for evaluating public health surveillance systems, which may be applied flexibly to

48 systems with varying goals [5,6]. The public health goal of widespread disease control and

49 elimination, like that for cholera in Bangladesh, requires the identification and monitoring of

50 areas with high case counts and high relative risk across the population in a timely manner.

51 However, quantitative evaluations of sensitivity are hard to obtain when the surveillance system 
medRxiv preprint doi: https://doi.org/10.1101/2021.06.02.21258249; this version posted June 5, 2021. The copyright holder for this preprint (which was not certified by peer review) is the author/funder, who has granted medRxiv a license to display the preprint in perpetuity.

It is made available under a CC-BY 4.0 International license.

52 is the sole source of data on the occurrence of disease; external data are needed to evaluate

53 the proportion of cases or outbreaks that are identified by the surveillance system $[7,8]$.

54 Our objective was to determine how the geographic coverage of Bangladesh's national

55 cholera sentinel surveillance system compares to the distribution of $V$. cholerae infection risk to

56 gauge how well the surveillance system is able to monitor progress towards national cholera

57 control. We also examined how alternate sentinel site selection might improve the sensitivity of

58 the surveillance system to detect high burden areas.

\section{Methods}

Cholera sentinel surveillance data

There are 23 healthcare facilities known to routinely perform laboratory confirmation of

V. cholerae among suspected cholera cases in Bangladesh, which includes the 22 sentinel

63 hospital sites in the national cholera surveillance system (in operation since 2016) and the

64 icddr,b Dhaka hospital (Supplementary Table 1). In the absence of specific data on healthcare

65 utilization for cholera at these sites, we assumed that the catchment areas of the different

66 healthcare facility types were as follows: subdistrict $(10 \mathrm{~km})$, district $(20 \mathrm{~km})$, tertiary care $(30 \mathrm{~km})$,

67 and the icddr,b Dhaka hospital (30km) (Figure 1). We refer to the joint set of buffers around all

6823 hospitals as the cholera surveillance zone, an estimate of the area where suspected cholera

69 cases may be tested and reported.

70

System sensitivity to detect high cholera case-burden

We used previously published maps of the estimated $V$. cholerae 01 seroincidence from

732015 as the presumed ground truth estimates of burden. These maps include national estimates

74 of the risk of $V$. cholerae 01 infection rates and relative infection risk (compared to the

75 population-weighted mean) across a $5 \mathrm{~km} \times 5 \mathrm{~km}$ grid of Bangladesh [2,9] (Supplementary

76 Figure 1A). 
medRxiv preprint doi: https://doi.org/10.1101/2021.06.02.21258249; this version posted June 5, 2021. The copyright holder for this preprint (which was not certified by peer review) is the author/funder, who has granted medRxiv a license to display the preprint in perpetuity. It is made available under a CC-BY 4.0 International license .

We defined the relative and absolute magnitudes of the infection risk and defined thresholds for high, moderate, and low relative and absolute risk across $25 \mathrm{~km}^{2}$ grid cells. We used the 25th and 75th percentiles of the mean grid cell-level risk (relative or absolute) to define cutoffs for moderate and high risk areas.

1. Relative risk: This is the seroincidence relative to the population-weighted mean proportion of infected individuals living in the cholera surveillance zone. Uncertainty in system sensitivity is reported with the 2.5th and 97.5th percentiles of 1000 posterior draws of the previously published gridded seroincidence estimates [2].

\section{Examining alternative sentinel site selection with a simulation-based approach}

We sought to determine whether system sensitivity could be improved with an alternate

97 hospitals in the Bangladesh Ministry of Health and Family Welfare Facility Registry using the R

98 package tidygeocoder [11] (See details in Supplementary Methods). The geocoded healthcare

99 facilities were then used to examine eight hypothetical strategies of sentinel site selection. The

100 total number of sites (23) and the distribution of facility types (i.e., 4 tertiary care facilities, 12

101 district-level facilities, and 6 upazila-level facilities) matched that of the current cholera

102 surveillance system across all strategies; we assumed that the system size would remain 103 constant. Only 22 new sites were selected for each set, as the icddr,b cholera hospital in Dhaka 
medRxiv preprint doi: https://doi.org/10.1101/2021.06.02.21258249; this version posted June 5, 2021. The copyright holder for this preprint (which was not certified by peer review) is the author/funder, who has granted medRxiv a license to display the preprint in perpetuity.

It is made available under a CC-BY 4.0 International license .

104 remained fixed as a site across all strategies. Twenty simulations (different sets of sites) were drawn per strategy based on a crude estimate of the possible number of unique sets of sentinel sites (491 total facilities/23 sites performing laboratory confirmation). We also estimated the sensitivity of a hypothetical surveillance system that would include all 491 large public hospitals. administrative units). The remaining six strategies weighted site selection by risk in an attempt

111 to prioritize high-risk areas (See details in Supplementary Methods). For each strategy, we

112 estimated the total population and the annual number of infected people in the proposed cholera

113 surveillance zone. We ran three linear regression models to partition sources of variability for

114 each selection strategy across surveillance zone infections with a random effect across (1000)

115 posterior draws for seroincidence risk and a random effect across (20) simulations in a given

116 strategy. The magnitude of the intraclass correlation coefficient (ICC) for the individual random

117 effect models indicates the relative variability explained by each factor. We reported confidence

118 intervals of system sensitivity as the 2.5 th and 97.5 th percentiles of the joint distribution of the

11920 simulations and 1000 posterior seroincidence draws.

\section{Code and reproducibility}

All analyses were performed in R. Data and source code to reproduce analyses are available at https://https://github.com/HopkinsIDD/bgd cholera greyspots with additional details

124 provided in the supplemental appendix. The underlying seroincidence estimates are available at https://github.com/HopkinsIDD/Bangladesh-Cholera-Serosurvey.

\section{Results}


medRxiv preprint doi: https://doi.org/10.1101/2021.06.02.21258249; this version posted June 5, 2021. The copyright holder for this preprint (which was not certified by peer review) is the author/funder, who has granted medRxiv a license to display the preprint in perpetuity. It is made available under a CC-BY 4.0 International license .

130 (clinically or subclinically) with V. cholerae O1 (Figure 1). The infections occurring in the cholera

131 surveillance zone accounted for $29 \%(95 \% \mathrm{Cl}: 27-35)$ of the 22.5 million $V$. cholerae 01

132 infections estimated for Bangladesh during the same period [2].

We estimated that 111.7 million (69\%) people in Bangladesh live in surveillance

134 greyspots, the geographic area outside of the cholera surveillance zone where suspected

135 cholera is unlikely to be confirmed (Figure 1). The cholera surveillance zone captured 3.4 million

$136(95 \% \mathrm{Cl}: 1.8-6.0)$ annual infected individuals living in high relative risk areas in Bangladesh;

$13774 \%$ (95\% Cl: $62-78 \%)$ of the at-risk population living in high relative risk areas in Bangladesh

138 lived in surveillance greyspots (Table S2). The cholera surveillance zone captured 3.6 million

139 (95\% Cl: 1.6-6.0) annual infected individuals living in moderate relative risk areas in

140 Bangladesh; 70\% (95\% Cl: 63-73\%) of the at-risk population living in moderate relative risk

141 areas in Bangladesh lived in surveillance greyspots. Individuals living in the districts of Rajshahi,

142 Kurigram, and Khulna had high relative infection risk but were unlikely to be captured by the

143 cholera sentinel surveillance system (Figure 2).

$144 \quad$ Using the absolute risk metric to define risk areas, the cholera surveillance zone

145 captured 6.2 million (95\% Cl: 3.5-9.2) annual infected individuals living in high absolute risk

146 areas in Bangladesh; 58\% (95\% Cl: 54-59\%) of the population living in high absolute risk areas

147 in Bangladesh lived in surveillance greyspots (Table S2). The cholera surveillance zone

148 captured 1.8 million (95\% Cl: $0.76-2.8)$ infected individuals living in moderate absolute risk

149 areas in Bangladesh; 78\% (95\% Cl: 74-80\%) of the at-risk population living in moderate

150 absolute risk areas in Bangladesh lived in surveillance greyspots.

Alternative sentinel site selection

Alternative sentinel site selection strategies employing the Random or Division selection

154 strategy captured a similar percentage of infected individuals in their cholera surveillance zones

155 (16\%, 95\% Cl: 9-23\% and 16\%, 95\% Cl: 9-24\%, respectively) as the current surveillance

156 system and more directed strategies such as the Relative Risk Equity and Absolute Risk Equity 
medRxiv preprint doi: https://doi.org/10.1101/2021.06.02.21258249; this version posted June 5, 2021. The copyright holder for this preprint (which was not certified by peer review) is the author/funder, who has granted medRxiv a license to display the preprint in perpetuity.

It is made available under a CC-BY 4.0 International license .

157 (18\%, 95\% Cl: 10-25\% and 17\%, 95\% Cl: 10-24\%, respectively). While percentage differences

158 were small, the mean number of infections captured varied by up to 1 million between some

159 pairs of strategies (Full results in Table S3). If all 491 public facilities were used in the

160 surveillance system, 97\% (95\% Cl: 96.6-97.5\%) of infections would be captured (27 million,

$16195 \% \mathrm{Cl}: 16.6-37.9)$.

162

An examination of the ICC across multiple models of infections in the cholera

163 surveillance zone revealed that there was substantially greater uncertainty in the underlying

164 seroincidence risk estimates than in simulations for the same strategy. The ICC ranged from

1650.84 to 0.97 for models with random effects on seroincidence posterior draws, while it ranged

166 only from 0.01 to 0.1 for models with random effects on simulations (full results in Table S4).

167 There were no major differences between strategies.

\section{Discussion}

The cholera sentinel surveillance system in Bangladesh is the only data source available

170 to monitor progress towards national disease control by 2030 . Our study described the

171 characteristics of cholera surveillance greyspots, geographic areas where cases are unlikely to

172 be detected because they reside outside the catchment areas of sentinel surveillance sites. We

173 estimated that roughly 111.7 million individuals (69\% of Bangladesh's population) live in

174 greyspots, and that $23 \%$ of these individuals (25.5 million people) live in areas with extremely

175 high risk of cholera infection (where the mean annual seroincidence rate is $22 \%$ ) (Figure 3 ). The

176 alternative methods for selecting sentinel sites that we explored produced only minor

177 improvements in the capture of cholera infections, although more optimized strategies could be

178 devised. Without changes to the surveillance system, it will be impossible to monitor high

179 cholera burden areas in much of the country, which is a substantive impediment to measuring

180 progress on elimination.

The original stated goals for Bangladesh's national cholera sentinel surveillance system

182 were to monitor cholera seasonality and epidemiology while also tracking the burden of disease 
medRxiv preprint doi: https://doi.org/10.1101/2021.06.02.21258249; this version posted June 5, 2021. The copyright holder for this preprint (which was not certified by peer review) is the author/funder, who has granted medRxiv a license to display the preprint in perpetuity.

It is made available under a CC-BY 4.0 International license .

183 in areas believed to have high prevalence; the objectives may not have had the disease

184 elimination goal in mind. Sentinel surveillance systems that are sensitive to capturing high risk

185 areas are critical to disease elimination efforts to measure disease burden, identify at-risk

186 populations, and monitor the health impacts of interventions in target populations. For cholera

187 control specifically, the drivers of disease transmission are highly local (i.e., fecal-contaminated

188 water and food), with great variation even between households, and campaigns against

189 waterborne diseases must be targeted effectively to high risk areas to achieve

190 success. Depending on whether risk is defined in relative or absolute terms, $58-74 \%$ of

191 individuals living in high risk areas were not captured within the cholera surveillance zone. While

192 it is often difficult to quantify the performance of a sentinel system to monitor high risk

193 populations, future work may use our framework to assess how multiple, simulated sentinel

194 selection site strategies may be better suited to achieving different system goals. For example,

195 choosing sites according to population density may best monitor geographic areas with high

196 absolute risk, while choosing sites that are dispersed across geographic divisions may create a

197 sentinel surveillance system that is most representative of national population-level disease

198 trends.

Selecting a strategy to increase overall surveillance sensitivity should consider both cost

200 and feasibility. For example, expanding the number of sites performing laboratory confirmation

201 would expand surveillance system sensitivity, but it may be too costly to be feasible.

202 Furthermore, including all public healthcare facilities in Bangladesh in as sentinel sites would

203 not result in 100\% capture of all infections. Future analyses may instead consider the impact of

204 one or more creative solutions, such as the placement of testing sites in select locations that are

205 hard-to-reach and that have high estimated infection risk, or widespread use of cholera rapid

206 diagnostic tests (RDTs). Although RDTs may have lower diagnostic specificity than other

207 laboratory confirmation methods (e.g., 96.5\% specificity with Cholkit vs $99.9 \%$ with culture) [12],

208 their relatively low cost (2 USD vs 6-8 USD with culture per unit, [13]) and ease of

209 implementation make them prime candidates for expanded use in settings with limited 
medRxiv preprint doi: https://doi.org/10.1101/2021.06.02.21258249; this version posted June 5, 2021. The copyright holder for this preprint (which was not certified by peer review) is the author/funder, who has granted medRxiv a license to display the preprint in perpetuity. It is made available under a CC-BY 4.0 International license .

210 laboratory capacity where the prime purpose for testing is surveillance, not clinical care

211 decisions. Though field evaluations in Bangladesh have demonstrated moderate sensitivity of

212 RDTs relative to culture (e.g., Crystal VC: $72 \%(95 \% \mathrm{Cl}: 51-88 \%)$ and Cholkit: $76 \%$ (95\% Cl:

$21355-91 \%$ [ [13]), culture tests are known to have a higher false negative rate when antibiotics

214 have been previously taken by the patient and are sensitive to transport conditions when testing

215 is centralized, so sensitivity of RDTs is likely higher than what has been reported [13]. If such

216 tests can be distributed nationally, as stated in the national cholera control plan, the

217 decentralization of testing by use of RDTs may lead to similar if not better performance, real-

218 time tests, and nationwide monitoring for widespread disease control may be feasible when

219 paired with other forms of surveillance.

220

Our approach has several limitations. We assumed that hospital catchment areas could

221 be defined with simple radial buffers, similar to previous work [14]. A more accurate approach to

222 estimating hospital catchment areas would use patient demographic, symptom, and home

223 address data, and account for barriers to healthcare seeking [15,16]; in reality, the cholera

224 surveillance zone is likely smaller than what we assumed resulting in overestimates of system

225 sensitivity. Conversely, the functional coverage of the cholera surveillance zone may be more

226 expansive than our stated assumptions if private clinics and facilities outside of the national

227 sentinel surveillance system use RDTs or culture to confirm suspected cholera cases, and

228 event-based surveillance systems like media surveillance and hotlines routinely detect disease

229 outbreaks, though samples still have to be processed and confirmed in a lab [17]. Discussions

230 with experts suggest that testing outside of the sentinel surveillance system is low, however,

231 and unlikely to change our results substantially. Finally, while clinical cholera incidence is almost

232 certainly lower than seroincidence, their geographic distributions of burden are likely to be

233 similar and our results should serve as a reasonable proxy for system sensitivity for clinical

234 cholera detection.

The surveillance evaluation framework proposed here, which aims to quantify

236 surveillance system sensitivity to monitoring large-scale reductions in cholera morbidity, may 
medRxiv preprint doi: https://doi.org/10.1101/2021.06.02.21258249; this version posted June 5, 2021. The copyright holder for this preprint (which was not certified by peer review) is the author/funder, who has granted medRxiv a license to display the preprint in perpetuity.

It is made available under a CC-BY 4.0 International license .

237 nonetheless prove useful in the context of nationwide control or elimination efforts for other

238 vaccine preventable diseases, like typhoid or Japanese encephalitis $[18,19]$. By comparing

239 surveillance data to an external validation instrument like a population-representative

240 serosurvey, it is possible to quantify surveillance system sensitivity and perform targeting of

241 interventions that can contribute to an effective elimination strategy. Beyond providing

242 surveillance metrics, an external validation instrument like cross-sectional serology can be used

243 to motivate specific system improvements such as the selection of alternate sentinel sites to

244 increase system sensitivity or even a more cost-effective surveillance system to capture the risk

245 of both asymptomatic and symptomatic infection. Further, by applying multiple definitions of

246 disease risk (e.g., relative versus absolute risk), we can identify surveillance greyspots that are

247 robust to multiple dimensions of information. For example, though the relative risk of $V$. cholerae

248 infection may be considered low in an urban area, the estimated absolute number of infections

249 could be high; we would not want sentinel surveillance sites to be concentrated only in high

250 relative risk areas. Monitoring changes in relative and absolute risk over time, and in rural

251 versus urban areas is important, especially as access to care changes.

Ultimately, the goal of public health surveillance systems are to generate data for action

253 towards improving public health, but if significant gaps in the surveillance system exist such

254 goals may never be met. In Bangladesh, the goal of cholera elimination will likely be hindered by

255 the lack of geographic or population coverage if changes to the system are not made; any

256 documented reductions in morbidity and mortality to quantitate progress will only be among $31 \%$

257 of the country's population. For any disease, a strong elimination plan should demand high

258 quality surveillance data and using more rigorous and cost-effective methods to evaluate

259 surveillance data is an imperative first step. 
medRxiv preprint doi: https://doi.org/10.1101/2021.06.02.21258249; this version posted June 5, 2021. The copyright holder for this preprint (which was not certified by peer review) is the author/funder, who has granted medRxiv a license to display the preprint in perpetuity.

It is made available under a CC-BY 4.0 International license .

\section{Tables \& Figures}

262 Figure 1. A map of the cholera greyspots in Bangladesh. Populations living in the coral pink areas

263 are inside the cholera surveillance zone. The grey areas are places where we have little information

264 on clinical cases of cholera as they are not captured by the national cholera surveillance system in

265 Bangladesh.

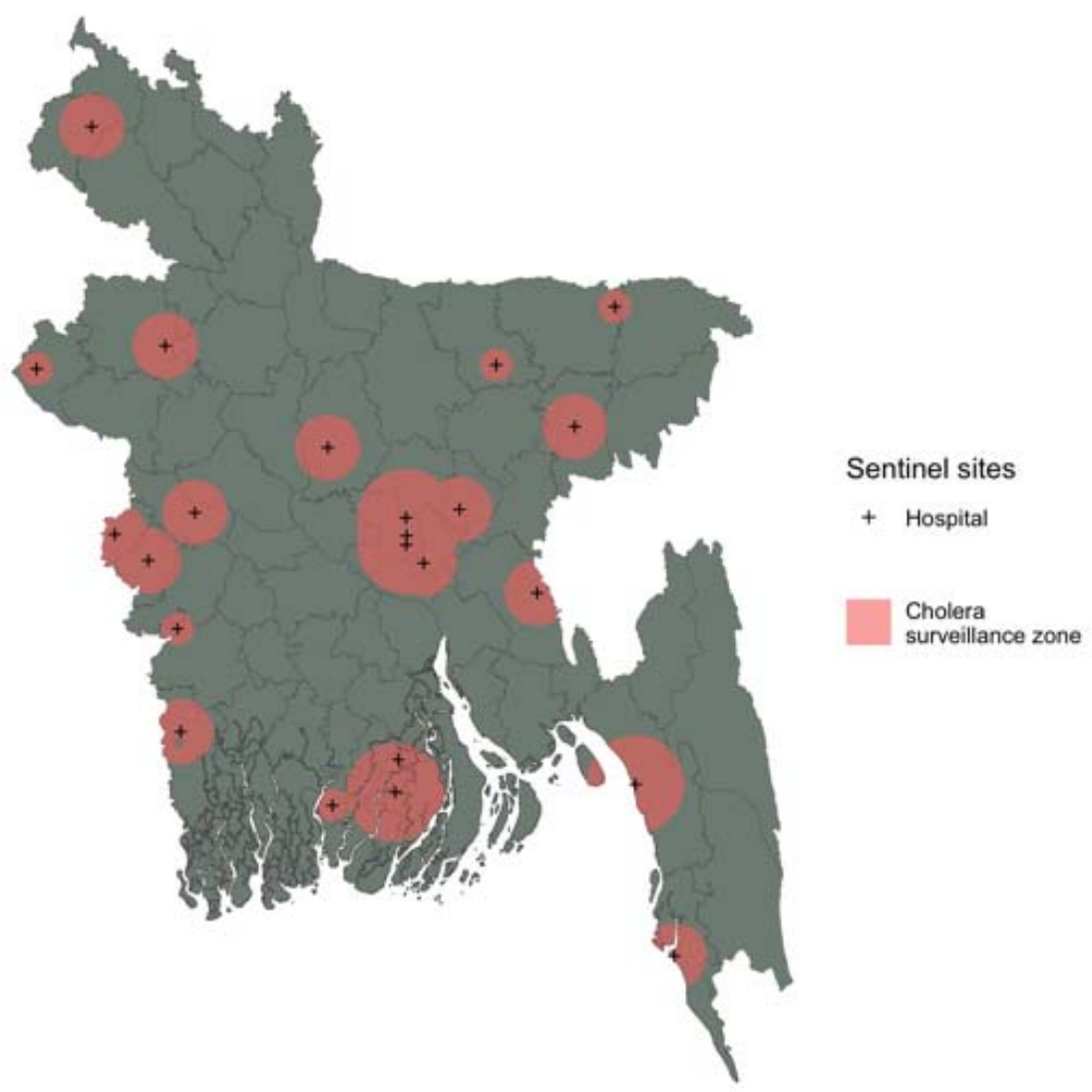


medRxiv preprint doi: https://doi.org/10.1101/2021.06.02.21258249; this version posted June 5, 2021. The copyright holder for this preprint (which was not certified by peer review) is the author/funder, who has granted medRxiv a license to display the preprint in perpetuity.

It is made available under a CC-BY 4.0 International license .

268 Figure 2. Cholera risk map as categorized by the risk of seroincidence relative to a population-

269 weighted mean by $5 \mathrm{~km} \times 5 \mathrm{~km}$ grid cell (Panel A). The map illustrates grid cells of High-Moderate-

270 Low risk and the which grid cells are captured by the cholera surveillance zone $(10-20-30-30 \mathrm{~km}$ for

271 subdistrict, district, and tertiary care, and icddr,b hospitals), indicated by the transparent buffers.

272 Cholera risk map as categorized by the estimated number of $V$. cholerae infections by $5 \mathrm{~km} \times 5 \mathrm{~km}$

273 grid cell (Panel B). The black marks indicate sentinel hospital locations and the transparent buffers

274 overlayed represent the cholera surveillance zone.

A

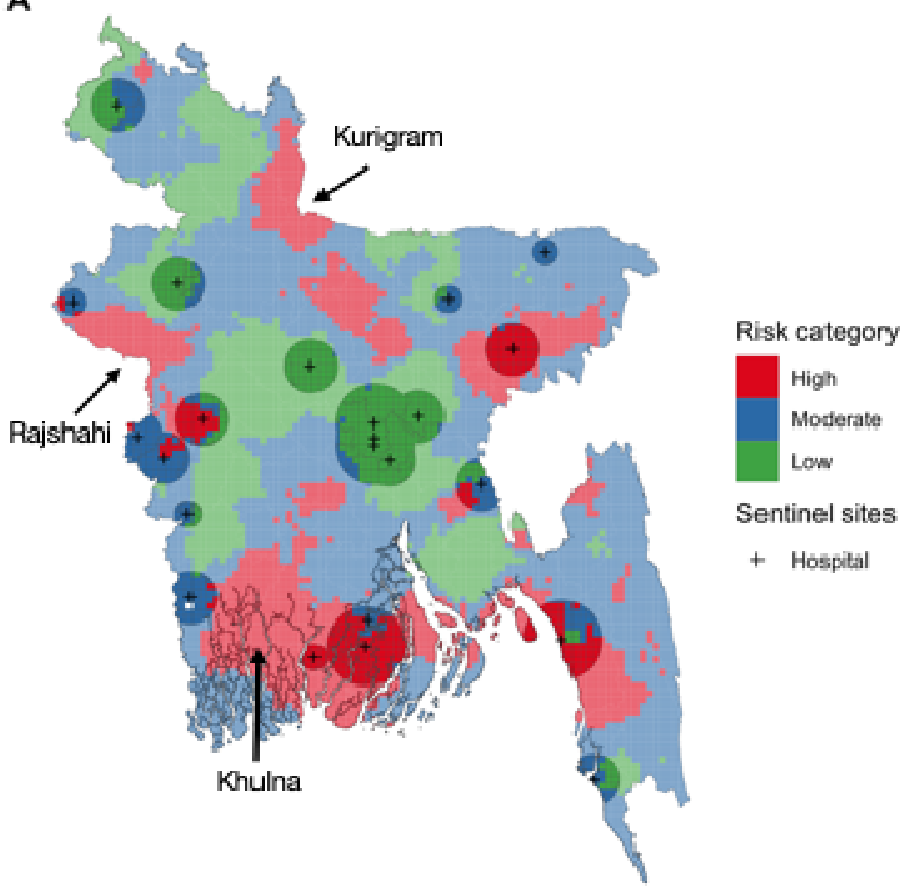

B

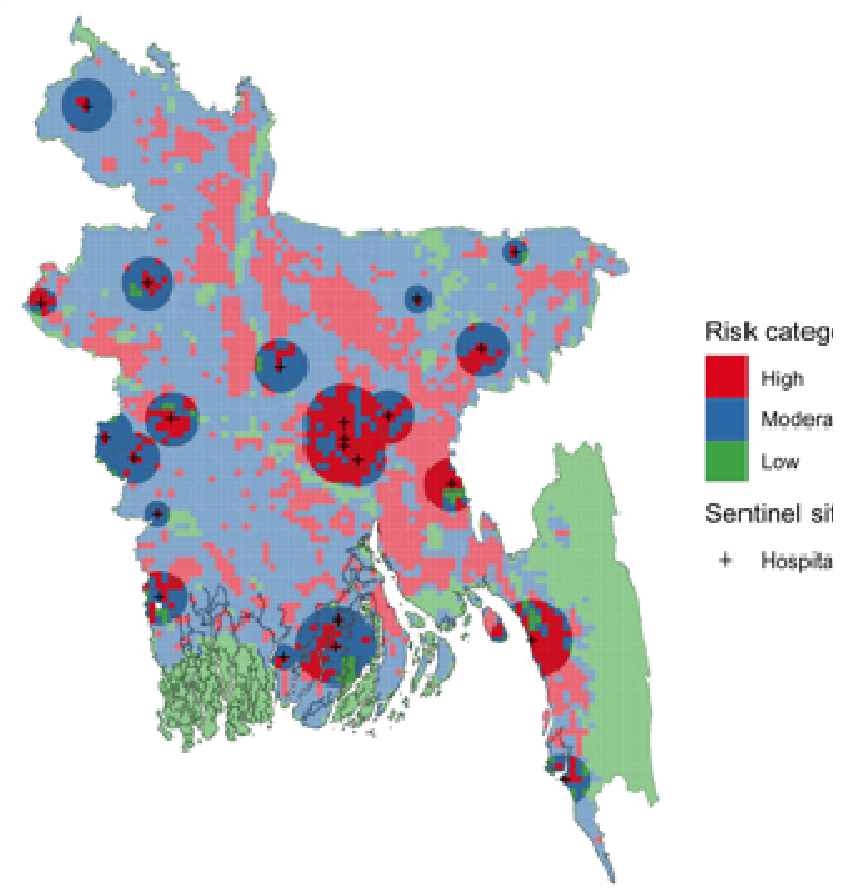


medRxiv preprint doi: https://doi.org/10.1101/2021.06.02.21258249; this version posted June 5, 2021. The copyright holder for this preprint (which was not certified by peer review) is the author/funder, who has granted medRxiv a license to display the preprint in perpetuity.

It is made available under a CC-BY 4.0 International license .

278 Figure 3. A. The number of people living in high-moderate-low risk areas as defined by the relative

279 and absolute risk metrics across Bangladesh and captured in the cholera surveillance zone (shown

280 in different shades as the geographic frame). The percentages in each bar represent the percentage

281 of the people living in high-moderate-low risk areas across Bangladesh that are captured in the

282 cholera surveillance zone. B. The number of people infected with $V$. cholerae living in high-

283 moderate-low risk areas as defined by the relative and absolute risk metrics across Bangladesh and

284 captured in the cholera surveillance zone (shown in different shades as the geographic frame). The

285 percentages in each bar represent the percentage of infected people living in high-moderate-low risk

286 areas across Bangladesh that are captured in the cholera surveillance zone.

A

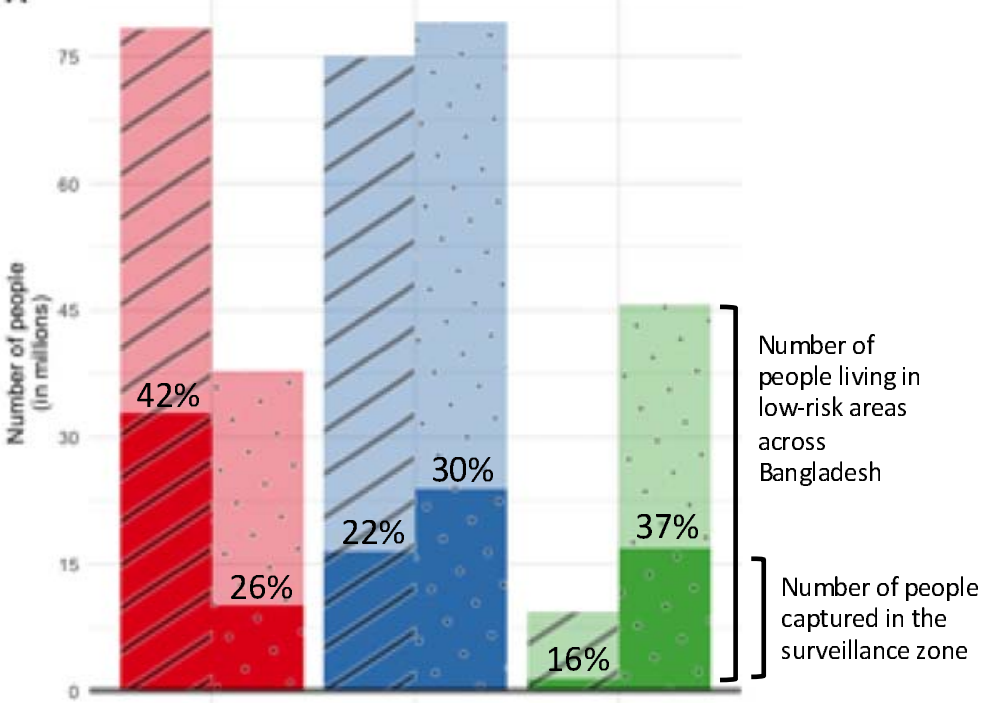

Risk metric

Absolute risk

$\because$ Relative risk

Geographic frame

Bangladesh

Surveillance zone

B

Risk cabegory

20

High

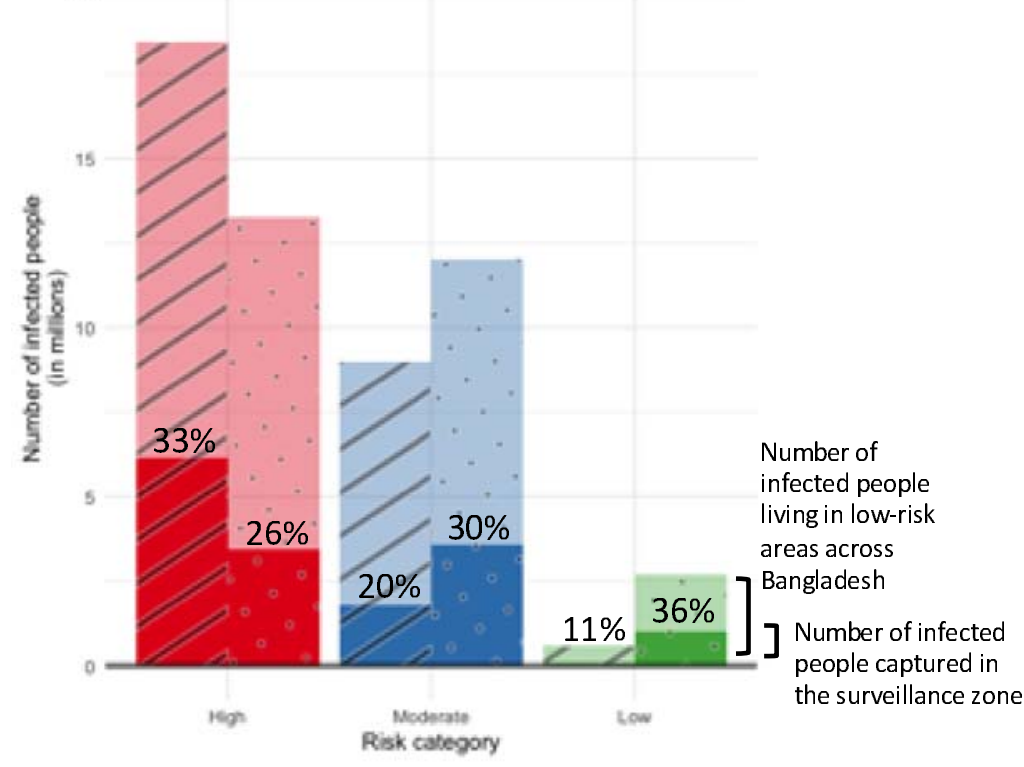

Risk metric

Absolute risk

$\because$ Relative risk

Geographic frame

Bangladesh

Surveillance zone

Risk categary 
medRxiv preprint doi: https://doi.org/10.1101/2021.06.02.21258249; this version posted June 5, 2021. The copyright holder for this preprint (which was not certified by peer review) is the author/funder, who has granted medRxiv a license to display the preprint in perpetuity.

It is made available under a CC-BY 4.0 International license .

\section{Acknowledgements}

289 This study was funded by the Bill \& Melinda Gates Foundation, National Institutes of Health, and

290 US Centers for Disease Control and Prevention. We thank study staff and participants across

291 Bangladesh for their support.

292

293 
medRxiv preprint doi: https://doi.org/10.1101/2021.06.02.21258249; this version posted June 5, 2021. The copyright holder for this preprint (which was not certified by peer review) is the author/funder, who has granted medRxiv a license to display the preprint in perpetuity.

It is made available under a CC-BY 4.0 International license.

References

1. Ali M, Lopez AL, You YA, et al. The global burden of cholera. Bull World Health Organ. 2012; 90(3):209-218A.

2. Azman AS, Lauer S, Taufiqur Rahman Bhuiyan M, et al. Vibrio Cholerae O1 Transmission in Bangladesh: Insights from a Nationally- Representative Serosurvey [Internet]. Available

3. Khan Al, Rashid MM, Islam MT, et al. Epidemiology of Cholera in Bangladesh: Findings From Nationwide Hospital-based Surveillance, 2014-2018. Clin Infect Dis [Internet]. 2019; .

4. DGHS, MOHFW, Government of Bangladesh. Practical approach to controlling cholera in Bangladesh through dual interventions of OCV \& WaSH [Internet]. Global Task Force on Cholera Control. 2019 [cited 2021 May 10]. Available from: https://www.gtfcc.org/wpcontent/uploads/2020/08/6th-annual-meeting-gtfcc-bangladesh.pdf

5. Centers for Disease Control (CDC). Guidelines for evaluating surveillance systems. MMWR Suppl. 1988; 37(5):1-18.

6. German RR, Lee LM, Horan JM, et al. Updated guidelines for evaluating public health surveillance systems: recommendations from the Guidelines Working Group. MMWR Recomm Rep. 2001; 50(RR-13):1-35; quiz CE1-7. Outbreak Detection in Bangladesh: Analysis of Healthcare Utilization Data. PLoS Med. 2017; 14(1):e1002218. number of Nipah outbreaks missed by hospital-based surveillance in Bangladesh. Int J 
medRxiv preprint doi: https://doi.org/10.1101/2021.06.02.21258249; this version posted June 5, 2021. The copyright holder for this preprint

(which was not certified by peer review) is the author/funder, who has granted medRxiv a license to display the preprint in perpetuity.

It is made available under a CC-BY 4.0 International license .

318 9. Azman AS, Lessler J, Luquero FJ, et al. Estimating cholera incidence with cross-sectional serology. Sci Transl Med [Internet]. 2019; 11(480). Available from:

320 http://dx.doi.org/10.1126/scitransImed.aau6242

321

10. Tatem AJ. WorldPop, open data for spatial demography. Sci Data. 2017; 4:170004.

322

323

324

325

326

327

328

329

330

331

332

333

334

335

336

11. Government of Bangladesh. Facility Registry [Internet]. [cited 2021 May 13]. Available from: http://facilityregistry.dghs.gov.bd/index.php

12. Sayeed MA, Islam K, Hossain M, et al. Development of a new dipstick (Cholkit) for rapid detection of Vibrio cholerae O1 in acute watery diarrheal stools. PLoS Negl Trop Dis. 2018; 12(3):e0006286.

13. Islam MT, Khan Al, Sayeed MA, et al. Field evaluation of a locally produced rapid diagnostic test for early detection of cholera in Bangladesh. PLoS Negl Trop Dis. 2019; 13(1):e0007124.

14. Government of the People's Republic of Bangladesh Ministry of Health and Family Welfare. Secondary and Tertiary Healthcare. Health Bull. 2012; :53-60.

15. Hierink F, Okiro EA, Flahault A, Ray N. The winding road to health: A systematic scoping review on the effect of geographical accessibility to health care on infectious diseases in low- and middle-income countries [Internet]. PLOS ONE. 2021. p. e0244921. Available from: http://dx.doi.org/10.1371/journal.pone.0244921

16. Mannan MA. Access to Public Health Facilities in Bangladesh: A Study on Facility Utilisation and Burden of Treatment. Bangladesh Dev Stud. Bangladesh Institute of Development Studies; 2013; 36(4):25-80.

17. Husain M, Rahman M, Alamgir A, Salim Uzzaman M, Flora MS. Disease Surveillance System of Bangladesh: Combating Public Health Emergencies. Online J Public Health Inform [Internet]. University of Illinois at Chicago Library; 2019 [cited 2021 May 2]; 11(1). 
medRxiv preprint doi: https://doi.org/10.1101/2021.06.02.21258249; this version posted June 5, 2021. The copyright holder for this preprint (which was not certified by peer review) is the author/funder, who has granted medRxiv a license to display the preprint in perpetuity.

It is made available under a CC-BY 4.0 International license .

342 Available from: https://www.ncbi.nlm.nih.gov/pmc/articles/PMC6606310/

343 18. Paul KK, Sazzad HMS, Rahman M, et al. Hospital-based surveillance for Japanese

$344 \quad$ encephalitis in Bangladesh, 2007-2016: Implications for introduction of immunization. Int J

$345 \quad$ Infect Dis. 2020; 99:69-74.

346 19. Heffelfinger JD, Li X, Batmunkh N, et al. Japanese Encephalitis Surveillance and

347 Immunization - Asia and Western Pacific Regions, 2016. MMWR Morb Mortal Wkly Rep.

$348 \quad 2017 ; 66(22): 579-583$.

349

350

351

352 